\title{
Michael and other archangels behind an eight-pointed cross-symbol from Medieval Nubia: A view from Sai Island in northern Sudan
}

\author{
Dr Henriette Hafsaas \\ Volda University College, Norway \\ E-mail:henriette.hafsaas@hivolda.no \\ Orcid id: https://orcid.org/0000-0001-8273-4427 \\ Dr Alexandros Tsakos \\ University of Bergen Library, Norway \\ E-mail:alexandros.tsakos@uib.no \\ Orcid id: https://orcid.org/0000-0001-8254-0964 \\ DOI: $\quad$ https://doi.org/10.46222/pharosjot.102.12
}

\begin{abstract}
The Christian population in Medieval Nubia created numerous manifestations of their faith in various forms - from monumental cathedrals to minuscule inscriptions. Among the latter are monograms, cryptograms, and cross-shaped symbols. Researchers of Medieval Nubia have only seldom studied closely these epigraphic categories. Moreover, the study of the cult of the archangels, especially of the archangel Michael, who held a primal position in the belief system of Christians in Nubia, has only recently attracted the attention of Nubiologists. This article employs theory about the interface between the written and the visual in order to discuss grapho-linguistic evidence for this type of epigraphic devices and the use of such devices as multivocal symbols in the cults of the archangels in Medieval Nubia. A careful analysis of cryptograms of the archangels Michael and Raphael offers a key to the decipherment of an eight-pointed cross as a multivocal symbol connected with the cult of the archangels. The study pivots around observations made during fieldwork on Sai Island in northern Sudan.
\end{abstract}

Keywords: Medieval Nubia, monograms, cryptograms, eight-pointed cross, cross symbols, archangels, Sai Island.

\section{Introduction}

Since we undertook archaeological fieldwork on Sai Island in northern Sudan more than a decade ago, we were spellbound by an eight-pointed cross appearing as a central motif on two of the capitals in the ruins of the medieval cathedral on the island (Figure 1).

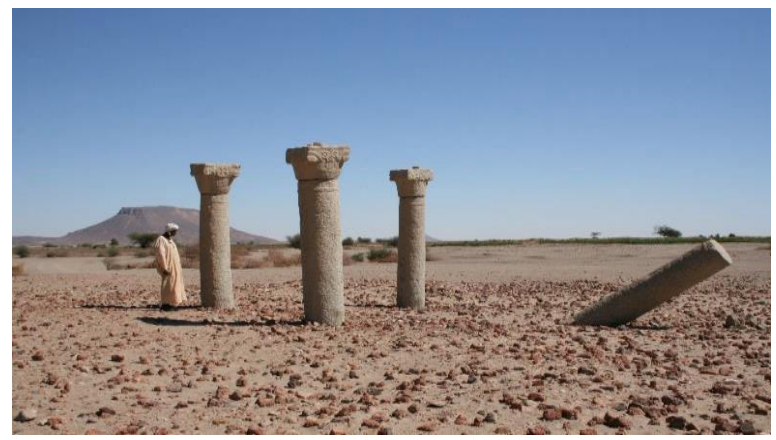

Figure 1: The columns and capitals of the ruined cathedral at site 8-B-500 on Sai Island (photo H. Hafsaas). 
This cross symbol is also known by the terms eight-pointed star, eight petal-rose, or star-cross (Gantzhorn, 1991: fig. 23, 36). The pattern was familiar to us from the kerchief of the traditional female customs in Norway and traditional mitten patterns in northern Europe. When we started looking for parallels explaining this symbol, it seemed to appear in a myriad of places and settings. Yet, the eight-pointed cross was uncommon in church architecture in Medieval Nubia, and it was rare as a decorative element in medieval churches elsewhere too. We investigated further about the meaning of the eight-pointed cross, but clear answers were difficult to find. The pattern itself has ancient and multiple roots, for instance as the eight-pointed star of Inanna/Ishtar - the Sumerian goddess (Black and Green, 1992: 169-170).

We observed the eight-pointed cross occasionally in Medieval Nubian contexts besides church architecture. Furthermore, the eight-pointed cross is particularly noticeable in Christian oriental carpets. They probably originated in Armenia around the fourth century CE with preChristian designs as forerunners and developed further in Islamic mosaics (Gantzhorn, 1991: $36,58,62$ ). The eight-pointed cross is clearly a symbol with multiple meanings depending on time, place, and context. Its meaning for Christians in Medieval Nubia began to be better apprehended when we started research on Christian cryptograms from different regions in Sudan. Then, a possible interpretation of the meaning of the eight-pointed cross in Medieval Nubia became apparent to us.

We begin this article with some relevant background information about Medieval Nubia. Then follows an outline of the theoretical perspective on grapho-linguistic techniques and multivocal symbols derived from ethnographic studies in Africa. To explain the interpretation of the eightpointed cross, we describe "graphic invocations" of (arch)angels with emphasis on Michael and the practice of writing cryptograms and monograms in Medieval Nubia. Nubiologists have rarely investigated the possible meanings behind monograms, cryptograms, and crosssymbols. Moreover, the study of the cult of the archangels - especially Michael - has only recently attracted the attention of researchers on Medieval Nubia.

The main contribution of this article is the decipherment of the eight-pointed cross and the following implications for a possible cult of Michael on Sai Island, as attested by architectural elements from the Cathedral of Sai. The meanings behind the Christian symbols in Medieval Nubia is a largely overlooked category of graphic devices. The decipherment of the eightpointed cross demonstrates that scholars of medieval Christianity in Nubia and elsewhere should pay closer attention to these symbols since they reveal the skills, abilities, and devotion of their creators.

\section{Medieval Nubia}

The Nile Valley south of Egypt is defined geographically by the passage of a series of rapids or cataracts, as the great river descends from the heart of Africa to the Mediterranean Sea. In the millennium considered as the medieval era, i.e. between roughly 500 and $1500 \mathrm{CE}^{1}$, the region of the cataracts, the Middle Nile Valley, was controlled by populations speaking a Nubian language and organized in at least three Christian kingdoms (Map 1).

\footnotetext{
${ }^{1}$ All chronological dates are CE.
} 


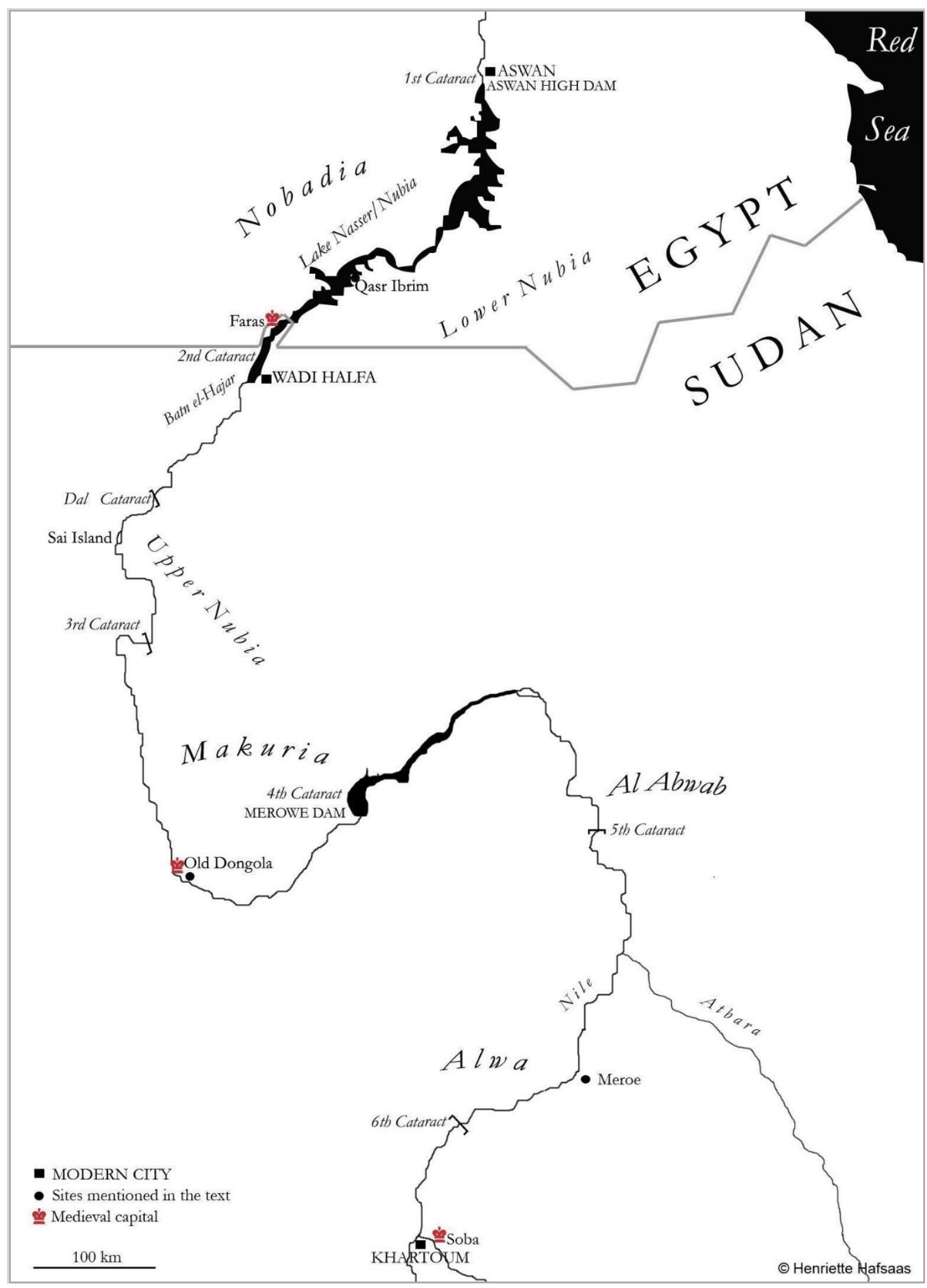

Map 1: Map of Medieval Nubia with sites mentioned in the text. Drawing by $\mathrm{H}$. Hafsaas.

- Alwa or Alodia, with its capital at Soba near Khartoum, the modern capital of Sudan, controlling Central Sudan from the Fifth Cataract or the junction of the Nile and the River Atbara to an unknown point towards South Sudan and Kordofan.

- Makuria, with its capital at Old Dongola, stretching between the borders with Alwa until the Third Cataract in the first centuries of Christian Nubia, and occupying also the regions further downstream until Aswan between the seventh century and the end of the medieval era. Around 
the turn from the first to second millennium, a local (i.e. Nubian) name for this kingdom appear in the written sources, namely Dotawo.

- Nobadia, with its capital at Faras or Qasr Ibrim, appearing at the end of Antiquity and the fall of the Meroitic kingdom in the first Cataracts of the Nile right south of Egypt and in direct dependence from it, culturally, economically, and often politically. During the Persian and Arabic invasions of the seventh century, Makuria annexed Nobadia and the latter was subsequently governed by an Eparch, subordinate to the Makuritan king.

Itinerant monks from Upper Egypt introduced the new religion among Nubians since the earliest times of the formation of the Nobadian state. The Evangelization of the kingdoms from Byzantium in the sixth century sealed a Christianization process in the north and created the necessary links with the kingdoms to the south. The royal courts of Dongola and Soba could thereafter consolidate their authority over the territories that they controlled under the Christian banner in Christianization processes that may have lasted until the eighth century for the upstream regions of Makuria, while the extent of the Christianization of the kingdom of Alwa remains unknown. However, during the missionary activities of the sixth century, there are reports of Christians from Axum already active at Soba.

In any case, several elements of the cultures of these three Christian kingdoms of the medieval centuries were common, notably the writing of the various forms of Nubian languages used in these regions by means of the Greek alphabet expanded with Coptic and Meroitic letters to satisfy phonetic needs of the local tongue not existing in Greek. The insistence on using this script is undoubtedly linked with the sacral aura with which Greek was imbued, since it was the language of the books of the New Testament, the foundational Holy Writ of the Christian faith.

This perceived sacral character of the Greek script bespeaks the importance of epigraphic activities for the Christians of Medieval Nubia, which admittedly is very impressive both in terms of number of known texts, creativity in contents, and beauty of writing styles. One of the most diagnostic characteristics of Nubian literacy is the epigraphic habit of writing up short texts as graffiti or dipinti on natural rock surfaces, built and plastered walls, ceramic vessels etc. And while exercising this habit, it is noteworthy that the Nubians used very often combinations of letters in forms of monograms and cryptograms. Although such practices appear in other regions of medieval Christianity too, as it can be observed for example in the vast corpus of Byzantine monograms, their presence in Christian Nubia has recently been explained in the framework of a new apprehension of how Christianity was practiced in the Middle Nile region: Apart from canonical forms, integrated into church hierarchy and scriptural doctrines, Nubian Christianity had a very pronounced apotropaic nature, full of what some may still call "magical" practices. We would like to see these practices as attempts to create ritually powerful expressions of the faith in order to achieve communication with the superhuman powers that lie beyond the reality that one perceives with the five senses and engage in a dialogue with them. It is against this background that there appeared in scholarship the idea that signs like monograms and cryptograms can be analyzed as grapho-linguistic techniques used by the Christians in Medieval Nubia.

\section{Grapho-linguistic and multivocal symbols}

Writing originated from the graphical arts - drawing, engraving, and painting - as "nonsignificant designs" became "endowed with meaning" and used for communication (Goody, 1987: 3-4). Research on information visualization indicates that the human brain is susceptible to perceive graphic lines with closed contours as objects, and such objects can in turn come to represent abstract concepts (Ware, 2013: 222-223). These cognitive abilities were fundamental for the abstraction needed to convert speech into writing, and this is taken a step further with complex signs such as monograms and cryptograms. Ildar Garipzanov (2015: 1) has argued that the use of graphic media, including monograms, in Late Antiquity and the early 
Medieval times, was "a mode of visual communication of conceptual information and abstract ideas". Cryptograms and cross symbols were other graphic media for communication of intricate ideas. Extralinguistic meanings were embedded in these graphic devices, and specialized skills were needed both to make these symbols and to interpret them (Garipzanov, 2015: 5). This is similar to the ideas of Jack Goody (1987: 274), who has argued that from early on in the history of writing, people have used grapho-linguistic techniques for abstraction by making "spatial layouts filled with linguistic items". Such manipulation of linguistic signs promotes problem-solving abilities, since communication through abstract linguistic and graphic signs increases both capacities and skills (Goody, 1987: 272-273). Goody's observations were informed by an anthropological case study of literacy among the Vai in West Africa. Another anthropological observation from Africa of relevance for the interpretation of the eight-pointed cross is Victor Turner's (1967: 50) study of the Ndembu in south-central Africa. He observed that multivocality is a significant property of many ritual symbols. Certain dominant symbols possess a multiplicity of meanings - from natural phenomena to abstract ideas - and thus allow for an efficient representation of key elements of the belief.

For almost two millennia, the cross has been a defining and multifaceted visual symbol of Christianity (Jensen, 2017). Angels are another diagnostic symbol of this religion (Gilhus, 2019). The decipherment of the eight-pointed cross will demonstrate how the cross-shape was used to invoke the archangels through a multivocal symbol that carried the meanings and protective powers of both the cross and the angels.

\section{Invoking the archangels}

The communication between humans and the divine realm has been postulated as possible through the intervention of messengers, like the goddess Iris in ancient Greece (Grimal, 1996), or the fravashis of Zoroastrianism (Boyce, 2000). Not coincidentally, these two examples of such intermediate beings are represented in art as winged figures, since the gods in a majority of religious beliefs are placed in the sky and the birds have therefore been seen as inhabiting a realm in between the earthly and the heavenly existence.

In Christianity, all these elements are at place: God is up in the Heavens; humans are down on earth; winged figures called angels connect the two spheres of existence. This is of course a very simplified image that has been nuanced in the diverse Christian traditions, like the moral teachings about the Fallen Angels (for example in 1 Enoch 7:2); the theological and ontological angelic hierarchies developed by Christian thinkers like Dionysios the Areopagite (Heil and Ritter, 2012); the "Gnostic" systems about the Pleroma and the Eons superimposing the human existence in matter and traversed by an enormous variety of intermediate beings (see for example King, 2005). These analytical categories are not exhaustive, but representative of what has been preserved in the surviving source material. The common denominator is that there is communication between "up-there" and "down-here" and this has been covered in the Christian mindset by beings called "angels", which is a Greek word meaning "messengers". Thus, the communication between God and humans can be perceived as a transfer of messages.

The Holy Scriptures, the miracles and apparitions are all constitutive elements in this mediated relationship, and the complexity of roles in the Christian cosmologies developed in the spectrum of Christian societies has invested specific angelic entities with the responsibility of "delivering" specific types of messages. For example, it was Gabriel who announced to Mary that she will bear the child Jesus (Luke 1:26-38); it is from Raphael that healing is expected (the name Raphael in Hebrew means "God has healed"); it is through Michael that humans can communicate with the divine realm their wishes through acts of ritual power, in what is often called "magic" (for Michael's role in magic, see Müller, 1959: 32-5). 
Such acts of ritual power can be both oral and written. In the former case, one thinks of prayers and chants; in the latter case, there is a large variety of categories of expression, like the painting of angelic figures and larger iconographic scenes, the drawing of symbols, and the composition of texts. Some of these categories overlap, as when an image is accompanied by a legend, or when a symbol consists of letters. It is this last category of means of communication with the divine realm that Christians have developed on the basis of their belief that the intermediate spheres of existence are populated by angels, i.e. messengers, that will be the focus of the first part of this study. In the second part, the decipherment of a complex symbol related with the cult of the archangel Michael will be proposed.

\title{
Symbols of archangels: cryptograms and monograms and their combinations
}

The invocation of superhuman beings through the pronouncement of their name is a wellknown practice across time periods and geographies. To state a topos, it is in the name of the Father, the Son and the Holy Spirit that Christians swear an oath, in both religious and profane contexts. Equally binding power has the writing of the names of the beings that populate the divine realm. A passage from the Sahidic Discourse on the Archangel Michael by Timothy, archbishop of Alexandria in the fourth century, preserved in a late tenth century manuscript from Upper Egypt (BL Or. 7029) is meaningful for the present study. Therein, Jesus himself states (see Łajtar and Van der Vliet, 2017: 73 for the translation):

\begin{abstract}
Because the name of Michael will be for them a strong armour. If someone write these glorious and $[\ldots]$ words upon the gates of his house ... no temptation of the Adversary will enter that house nor will plots of evil men be able to prevail over it. But let anybody who is going to copy it for himself as an amulet take care that this covenant (scil. The 'secret book' transmitted by the author) will not be deposited in a place where there is defilement, for great is the power of these wonderful names.
\end{abstract}

The "names" that Jesus refers to are not words written in full, but a series of numbers using the Greek alphabet, as known from ancient times (Dornseiff, 1925) and testified in the earliest Christian sources (e.g. Epistle of Barnabas 9:7-8). The ancient Greeks initially wrote numbers based on the letters of the Greek alphabet using the system outlined in table 1.

Table 1: The numerical system based on the Greek alphabet from 1 to 999 . The thousands are marked from the first series with a stress added next to the letter.

\begin{tabular}{|l|l|l|l|l|l|l|l|l|l|}
\hline Number & 1 & 2 & 3 & 4 & 5 & 6 & 7 & 8 & 9 \\
\hline Letter & $\mathrm{d}$ & $\mathrm{B}$ & $\mathrm{r}$ & $\Delta$ & $\epsilon$ & $\mathrm{L}$ & $\mathrm{Z}$ & $\mathrm{H}$ & $\Theta$ \\
\hline Number & 10 & 20 & 30 & 40 & 50 & 60 & 70 & 80 & 90 \\
\hline Letter & $\mathrm{I}$ & $\mathrm{K}$ & $\mathrm{A}$ & $\mathrm{M}$ & $\mathrm{N}$ & $\mathrm{z}$ & $\mathrm{O}$ & $\mathrm{n}$ & $\mathrm{Q}$ \\
\hline Number & 100 & 200 & 300 & 400 & 500 & 600 & 700 & 800 & 900 \\
\hline Letter & $\mathrm{P}$ & $\mathrm{C}$ & $\mathrm{T}$ & $\mathrm{V}$ & $\phi$ & $\mathrm{x}$ & $\psi$ & $\omega$ & $\lambda$ \\
\hline
\end{tabular}

In Nubia, the practice was very popular (see Łajtar and Van der Vliet, 2017: 72-4 for discussion and literature). The most widespread of these numeric names was $\mathrm{\Pi \Theta}$. According to the Greek system described in Table 1, this is the number 689. The number hides another word comprising the letters adding up the sum. This name is no other than that of the archangel Michael in Greek: MIYAH $\wedge$. The letters of the name consist of the following numeric values: $M=40, I=10, X=600, A=1, H=8$, and $\Lambda=30 ;$ or $40+10+600+1+9+30=689=Y \sqcap \Theta$. These "numeric names" are called "cryptograms". Among the dozens of such cryptograms attested, the names of the other archangels are also known, for example, PN $\triangle$ for $\Gamma A B P I H \wedge: \Gamma=3, A=1, B=2$, $\mathrm{P}=100, \mathrm{I}=10, \mathrm{H}=8$ and $\Lambda=30$, or $3+1+2+100+10+8+30=154=\mathrm{PN} \Delta$; and $\mathrm{XM}$ for $\mathrm{PAФAH} \wedge$ : $P=100, A=1, \Phi=500, A=1, H=8$ and $\Lambda=30$, or $100+1+500+1+8+30=640=X M$. 
Cryptograms were common in Nubia throughout the medieval period. The Database of Medieval Nubian Texts (DBMNT) records the cryptogram of the archangel Michael 49 times, while the cryptogram of the archangel Gabriel appears three times and Raphael once.

\begin{tabular}{|c|c|c|c|c|c|c|c|c|c|}
\hline \multirow{2}{*}{$\begin{array}{l}\text { DMNT } \\
\text { no. }\end{array}$} & \multirow[t]{2}{*}{ Object } & \multirow[t]{2}{*}{ Provenance } & \multirow[t]{2}{*}{ Language } & \multicolumn{6}{|c|}{ Date century } \\
\hline & & & & 9 & 10 & 11 & 12 & 13 & 14 \\
\hline 2386 & pottery & Abdallah-n Irqi & unidentified & & & $x$ & $x$ & & \\
\hline 2384 & wall & Abdallah-n Irqi & unidentified & & $x$ & & & & \\
\hline 2458 & pottery & Abkanarti & unidentified & & & & & & \\
\hline 2460 & pottery & Abkanarti & unidentified & & & & & & \\
\hline 1413 & pottery & Aksha & unidentified & & $x$ & & & & \\
\hline 1510 & wall & Amada & unidentified & & & & & & \\
\hline 2717 & pottery & Arminna West & unidentified & & & & & & \\
\hline 2611 & pottery & Debeira West & Greek & $\bar{x}$ & $\bar{x}$ & $x$ & & & \\
\hline 1353 & pottery & Dongola & unidentified & & & & $\bar{x}$ & $\bar{x}$ & \\
\hline 2000 & wall & Dongola & Greek & & & & $x$ & $x$ & \\
\hline 1803 & pottery & Faras & unidentified & & & & & & \\
\hline 2089 & wall & Faras & unidentified & & & & & & \\
\hline 2090 & pottery & Faras & unidentified & $x$ & $x$ & & & & \\
\hline 2124 & wall & Faras & unidentified & & & & & & \\
\hline 2871 & stone block & Faras & unidentified & & & & & & \\
\hline 2267 & ostrakon & Faras & unidentified & & & & & & \\
\hline 2516 & pottery & Ghazali & unidentified & & & & & & \\
\hline 2552 & pottery & Ghazali & unidentified & & & & & & \\
\hline 2564 & pottery & Ghazali & unidentified & & & & & & \\
\hline 2582 & pottery & Ghazali & unidentified & & & & & & \\
\hline 2497 & pottery & Ghazali & unidentified & & & & & & \\
\hline 2360 & pottery & Ghazali & unidentified & & & & & & \\
\hline 2426 & pottery & Kulb & unidentified & $\bar{x}$ & $\bar{x}$ & & & & \\
\hline 2427 & pottery & Kulb & unidentified & $\bar{x}$ & $x$ & & & & \\
\hline 2428 & pottery & Kulb & unidentified & $\bar{x}$ & $\bar{x}$ & & & & \\
\hline 2429 & pottery & Kulb & unidentified & $\bar{x}$ & $\bar{x}$ & $\bar{x}$ & & & \\
\hline 2430 & pottery & Kulb & unidentified & $x$ & & & & & \\
\hline 2431 & pottery & Kulb & unidentified & $\bar{x}$ & $x$ & & & & \\
\hline 2432 & pottery & Kulb & unidentified & $\bar{x}$ & $\bar{x}$ & $\mathrm{x}$ & & & \\
\hline 1235 & wall & Meinarti & unidentified & & & $\bar{x}$ & & & \\
\hline 1241 & pottery & Meinarti & unidentified & & & $\bar{x}$ & & & \\
\hline 1248 & jewellery & Meinarti & unidentified & & & $\bar{x}$ & & & \\
\hline 1230 & wall & Meinarti & Greek & & & $\bar{x}$ & & & \\
\hline 1250 & unidentified & Meinarti & unidentified & & & & $x$ & & \\
\hline 745 & stone block & Qasr Ibrim & unidentified & & & & & & \\
\hline 848 & jewellery & Qasr Ibrim & unidentified & & & & $x$ & $\bar{x}$ & \\
\hline 849 & stamp & Qasr Ibrim & unidentified & & & & $\bar{x}$ & $\bar{x}$ & \\
\hline 2451 & mudstopper & Qasr Ibrim & unidentified & & & & $\bar{x}$ & $x$ & \\
\hline 1963 & pottery & Soba & unidentified & & & & & & \\
\hline 1964 & pottery & Soba & unidentified & & & & & & \\
\hline 1965 & pottery & Soba & unidentified & & & & & & \\
\hline 1966 & pottery & Soba & unidentified & & & & & & \\
\hline 1927 & pottery & Soba & unidentified & & & & & & \\
\hline 1944 & pottery & Soba & unidentified & & & & & & \\
\hline 1897 & ostrakon & Soba & unidentified & & & & & & \\
\hline 2330 & wall & Tamit & unidentified & & & & & $x$ & $\mathrm{x}$ \\
\hline 2401 & rock & Us Island & unidentified & & & & & & \\
\hline 2417 & rock & Us Island & unidentified & & & & & & \\
\hline 2424 & pottery & Us Island & unidentified & & & & & & \\
\hline Total & & 15 sites & Greek: 3 & 9 & 10 & 8 & 7 & 6 & 1 \\
\hline
\end{tabular}

Table 2: Cryptograms of Michael in the Database of Medieval Nubian Texts, (DBMNT), http://www.dbmnt.uw.edu.pl/ Composed by Dr. Grzegorz Ochała. Last accessed April 2021. 
This overview of cryptograms of archangels in Medieval Nubia is not exhaustive, as thousands of unpublished texts are still missing from the database (Łajtar and Ochała, 2021: 790). According to current knowledge, however, Michael was the most popular archangel invoked in cryptograms in Nubia. This is timely since the name of the archangel Michael is the most frequently attested name in Nubia - occurring both in popular religious texts and in graffiti on, for instance, house walls. The archangel Michael was clearly the most popular divine figure in Nubian folk religion (Adams, 1993: 36). Another type of cryptogram is functioning in a manner described as indexical or iconic. In these cryptograms, the name of a given divine being is not "hidden" behind a number, as described above, but rather the first letter of his or her name is arranged in a manner reminiscent of painted representations of these holy figures. The best example of such a practice from Nubia is the trigram MX厂, standing for $M(I X A H \wedge), X(P I C T O C)$ and $\Gamma(\mathrm{ABPIH} \wedge)$, which is one of the most popular iconographic types of a Deesis, a scene of veneration of Christ or the Virgin Mary (Tsakos, 2015). In a chapel from the cathedral of Faras, the capital city of Nobadia, an eloquent example of this iconographic type can be observed. The three murals that constitute this scene can be seen today at the Sudan National Museum in Khartoum (Figure 2): Christ Emmanuel (SNM 32116) is flanked by the archangel Michael on the left (SNM 24373) and the archangel Gabriel on the right (SNM24328).

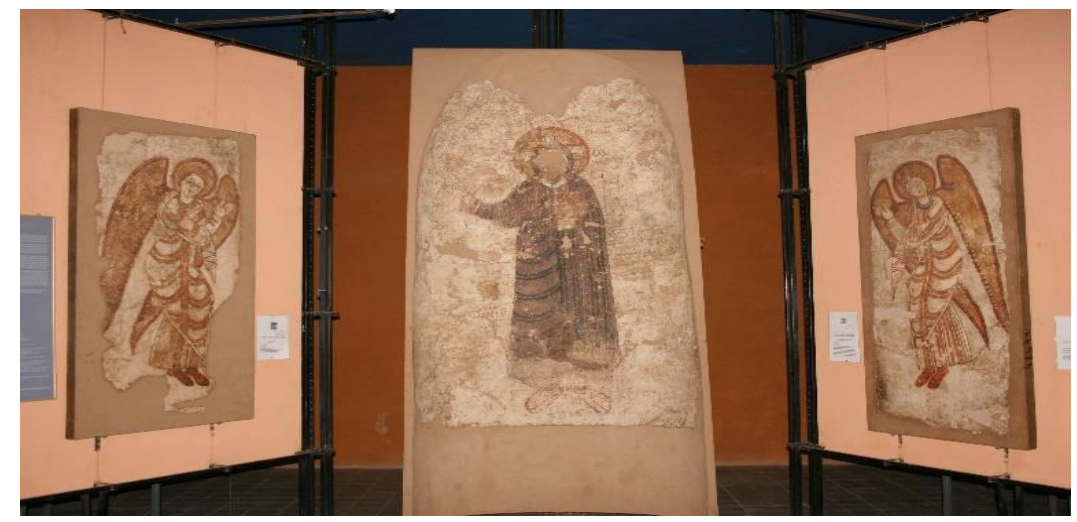

Figure 2: The Adoration of Christ by the Archangels Michael and Gabriel from the Cathedral at Faras as reconstructed in the Sudan National Museum (photo A. Tsakos).

Both in Christian Nubia and in other regions of Early and Medieval Christianity, monograms are another set of symbols functioning as invocations of the (arch)angelic powers. Monograms are more widespread scribal customs, recurrent in Byzantium and the medieval west (Garipzanov, 2015: 6), but also in modern practices, both profane and religious. The standard form is that the letters of a given name are written in a manner that they reproduce the shape of the cross, either by "hanging" by a cross-form, or by creating a cross-form with the way they are arranged (Tsakos, forthcoming a). In Nubia, there are numerous examples of both types of monograms, as can be seen in Figures $\mathbf{3 a} \mathbf{a} \mathbf{b}$.
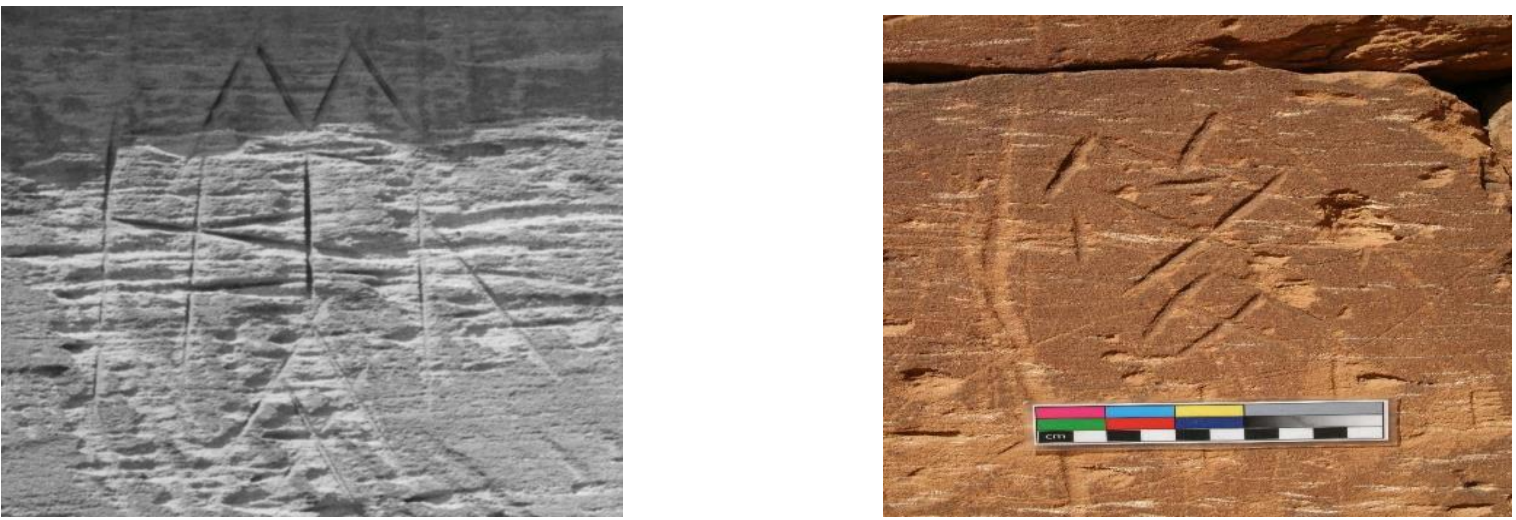

Figure 3: Two monograms of the archangel Michael from the pyramids at Meroë representing the two types of letter arrangement, i.e. (a) hanging from the cross and (b) forming a cross (photo C. Kleinitz) 
The latter type of these cross-shaped monograms is reminiscent of what is called "box monograms", where the letters of a given name are placed overlapping each other inside the frame of a box. The result of applying this type of monogrammatic rendering of names in the case of some of the archangels creates a very particular "box monogram" that should rather be called "winged monogram" since it is centered on a large X, which constitutes the core of a pair of wings. In Figure $\mathbf{4 a}$, one can see a $M$ with its diagonals coinciding with the upper half of the center of the letter $X$ and its verticals "closing" the $X$-shape from the sides. Here, the pair of wings is perfectly shaped.

a)

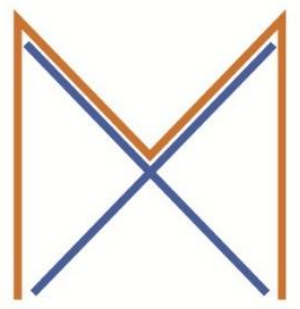

b)

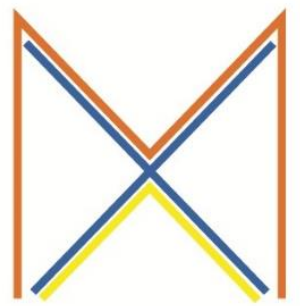

c)

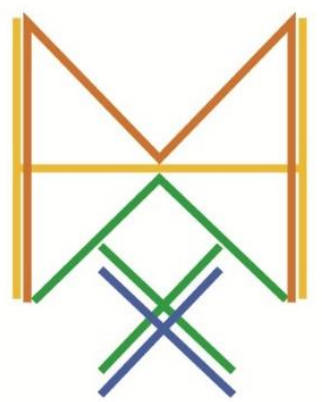

Figure 4: Schematic representations of winged monograms. a) Monogram for the cryptogram of the archangel Raphael (see below). b) Abbreviated monogram for archangel Michael. c) Complete monogram for archangel Michael. Drawing by Jens Weschenfelder.

In Figure $\mathbf{4 b}$, one can observe, in addition, that the lower half of the diagonals of our $\mathrm{X}$ can "contain" a $\Lambda$, and now the three letters $M, X$, and $\Lambda$ can very well represent an attested abbreviation $\mathrm{M}(\mathrm{I}) \mathrm{X}(\mathrm{AH}) \wedge$ of the archangel's name. Often this basic wing-shape was traversed horizontally by a line across the center of the $\mathrm{X}$, as presented in Figure 4c, creating an $\mathrm{H}$ with the vertical lines of the $M$, while another $X$ was added at the bottom of the one from which this line of thought began. This shape renders an epigraphic majuscule $A$ and thus forms the complete name of the archangel Michael as a monogram made with the fewest possible lines.

Finally, this complete wing-monogram of Michael could have a cross at its top, as is shown in Figure 5.
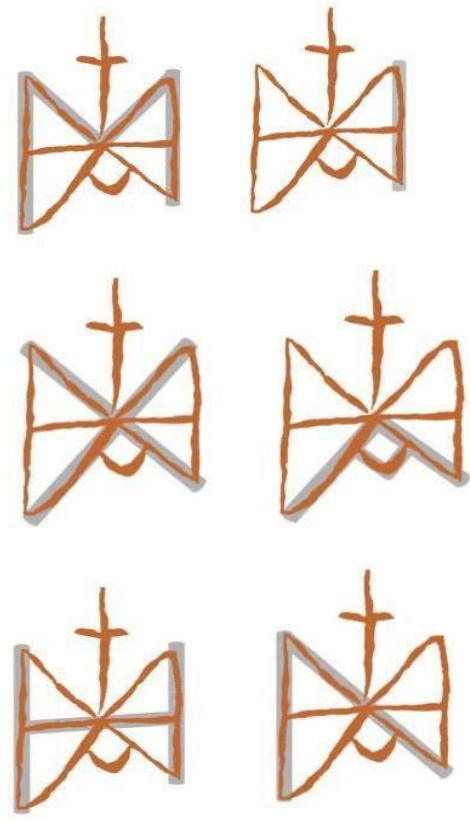

Figure 5: The complete monogram of the archangel Michael's name as a tattoo from a body found in the Fourth Cataract region, Sudan (reproduced from Vandenbeusch and Daniel). 
Now, we understand the simplest form of these "winged symbols" (see Figure 4a \& 6) as the rendering in monogrammatic form of the cryptogram of Raphael (i.e. XM) by superimposing the two letters that constitute this cryptogram. The identification of this scribal custom (see Tsakos, forthcoming a) opens the path for investigating the potential of such decipherments against other cryptograms and other cross shapes.

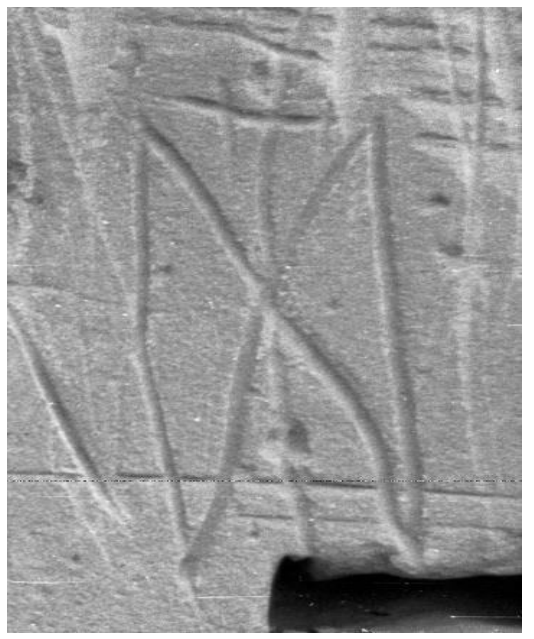

Figure 6: A graffito from the pyramids at Meroe with the cryptogram for the name of the archangel Raphael as a wing-monogram (photo C. Kleinitz).

All the variants of cryptograms and monograms mentioned above appear in medieval contexts in Nubia. We propose that the writing of cryptograms and monograms in Nubia were practiced as grapho-linguistic techniques in Goody's terminology (see above). These writings became visual symbols that the believers saw rather than read through a "conflation of text and graphic image" (Garipzanov, 2015: 8). The writing of the names of archangels in this way was probably a form of invoking them for protection (see Tsakos, forthcoming a for a more developed analysis of the ideas presented briefly here). This iconic value of script takes its form par excellence in our decipherment of the eight-pointed cross in the following section.

\section{The eight-pointed cross on Sai Island}

Sai Island was the location of one of the medieval bishoprics in Medieval Nubia as attested in both written and archaeological sources (Hafsaas-Tsakos and Tsakos, 2016: 391-393; Godlewski, 2019: 933). The island was initially part of the kingdom of Nobadia, but the region was incorporated into Makuria together with the rest of Nobadia - probably in the seventh century (Hafsaas-Tsakos and Tsakos, 2009; 82; Ruffini, 2021: 762).

The site considered to be the Cathedral of Sai consists of four grey columns with a height of more than 3 meters above the present surface (see Figure 1). Three of the columns are still standing straight with capitals in situ on the column shafts. The fourth column is tilted, and the capital has fallen down some meters away. We have recorded fragments of red bricks, sandstone, plaster, and terracotta window grilles on the surface around the columns, and this strengthens the interpretation of the site as the remains of a church (Hafsaas-Tsakos and Tsakos, 2009: 79). Three column bases are located 50 meters to the north of the columns. Excavations around the bases verified that they were not part of any building at their present location (Hafsaas-Tsakos and Tsakos, 2012: 83). The bases are of the same kind of granite as the columns, and their respective diameters match. We found a similar base inside the fortress of Sai (Hafsaas-Tsakos and Tsakos, 2009: 79). A medieval Christian cemetery is situated to the east of the column bases, and fragments of two terracotta funerary stelae have been found scattered around the site (Tsakos, 2011-2012). Several medieval cathedrals in Nubia saw multiple building phases, and we have previously argued for successive building 
phases for the cathedral of Sai too (Hafsaas-Tsakos and Tsakos, 2016: 407). Over the years, archaeologists have found numerous sandstone blocks with architectural elements from a church inside the fortress of Sai. Some of these spolia are probably the remains of the earliest cathedral on Sai and date to the sixth century (Hafsaas-Tsakos and Tsakos, 2016: 393). After the annexation by Makuria, a cathedral with granite columns was constructed on Sai in the early eighth century with the so-called Church of Granite Columns at Old Dongola as inspiration. This cathedral was probably built inside the fortress, as suggested by the fourth base and other church spolia found there (Hafsaas-Tsakos and Tsakos, 2016: 407). Furthermore, six funerary stelae of bishops of Sai have been found inside the fortress, supporting the fortress as the location of the earlier cathedrals (Tsakos, 2011-2012: Table 1 and pp. 329-30). Finally, a late church was built reusing the granite columns of the cathedral, and this is the current ruin of the Cathedral of Sai on site 8-B-500 (Hafsaas-Tsakos and Tsakos, 2016: 407).

Significant for the topic of this article is the central motif of two of the granite capitals of the Cathedral of Sai (see Hafsaas-Tsakos and Tsakos, 2016 for a more detailed description of the architectural elements in granite). All four granite capitals from Sai belong to the "massive structurally compact" type in Ida Ryl-Preibisz's typology of capitals from Old Dongola. The style dates to the late seventh and early eighth century (Ryl-Preibisz, 2001: 368, Fig. 1/c/1-2). The central motifs of this type of capital consist of various cross symbols (Ryl-Preibisz, 2001: 374375, Fig. 8). At Sai, the north-eastern capital and the fallen southwestern capital were decorated in the typical form of this style. However, the north-western and south-eastern capitals are of a less ordinary type. They have the massive form, but the decoration of the overhanging corners consists of broad concentric half-circles (see Gartkiewicz, 1990: 195). This is probably highly stylized representations of volutes. Furthermore, a rare wreath of halfcircles decorates the upper part of the cylindrical portion of the capital. Still, the most intriguing decorative element of these two capitals is an extraordinary central motif: a rare cross-shape consisting of arms of equal length and distinguishing v-shaped indentation of the arms (Figure 7).

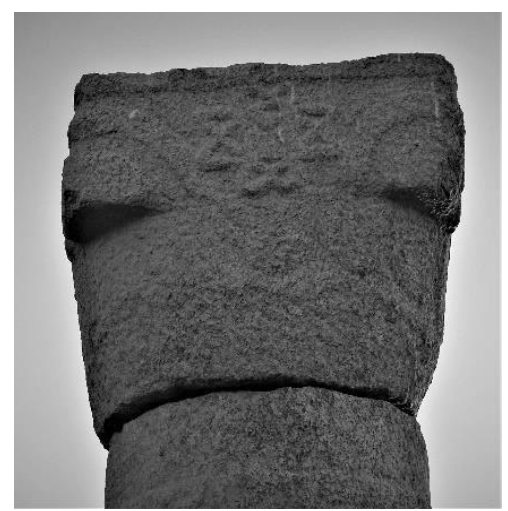

Figure 7: The eight-pointed cross on one of the column capitals from the so-called cathedral of Sai Island (photo H. Hafsaas).

The eight-pointed cross is rare in the architectural decoration of medieval churches in Nubia. On Sai, however, we find it on three of four faces of the north-western capital and two faces of the south-eastern capital. Elsewhere in Nubia, we have only been able to find this cross-shape on a capital from Faras (see Ryl-Preibisz, 1971: PI. XI/18b) and a voussoir stone from Qasr Ibrim (see Aldsworth, 2010: PI. 188, Fig. 40). The other faces of these capitals have more conventional crosses as central motifs. It was common in Medieval Nubia for the massive structurally compact capitals to have different central motifs on the four faces, just as it was common for the capitals of one set to be slightly different from one another (Ryl-Preibisz, 2001: 375). So, the variations in the decoration of the capitals on Sai are not unique. Conversely, the use of the eight-pointed cross on the capitals from Sai are more exceptional. Both their raison d'être on Sai and the more general interpretation of the symbol have puzzled us since we first 
conducted fieldwork on the island. It now appears that the systematic analysis of the different types of cryptograms used by Christians in Medieval Nubia, and especially the superimposing manner of their representations as "winged-monograms", as presented in from the previous section, offer a key for understanding this peculiar cross-shape.

So, when the letters of the cryptogram MYГ are superimposed in the monogrammatic technique (see above), then the cryptogram fits the lines of the arms of the eight-pointed cross (Figure 8).

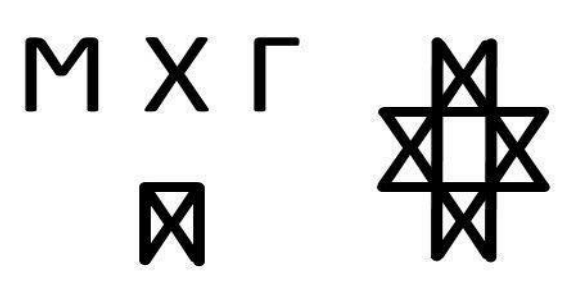

Figure 8: MY $\Gamma$ forming the eight-pointed cross (drawing by $\mathrm{H}$. Hafsaas).

Above, we suggested that the trigram MYГ was a graphic-linguistic representation of the archangels Michael and Gabriel flanking the Christ: $M$ for міхан $\lambda, Y$ for хрістос and $\Gamma$ for $г а в р і н \lambda$. The eight-pointed cross takes the graphic linguistic representation a step further since the meaning is no longer expressed through the letters but as a symbol. This is part of a more widespread early medieval practice where text and image were merged to carry extralinguistic meanings (Garipzanov, 2015: 5). MYГ is not the only option for fitting the eight-pointed cross with a cryptogram. The monogrammatic rendering of the cryptogram YM for Raphael gives an open eight-pointed cross. When the letters of the cryptogram of Raphael are superimposed, the "wings" of the archangel become the basic element of the arms of the cross (Figure 9).

\section{$M X$ \\ 内

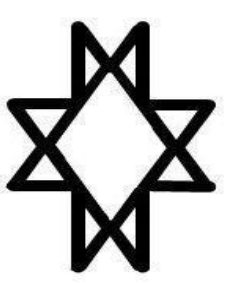

Figure 9: The archangel Raphael's cryptogram forming the eight-pointed cross (drawing by $\mathrm{H}$. Hafsaas).

Furthermore, such engraved wing symbols abound in Nubia, and we propose that it is a grapho-linguistic symbol not only for Raphael but for all archangels in general. We have also noted such wing-symbols as graffiti on architectural spolia in the fortress of Sai (Figure 10).

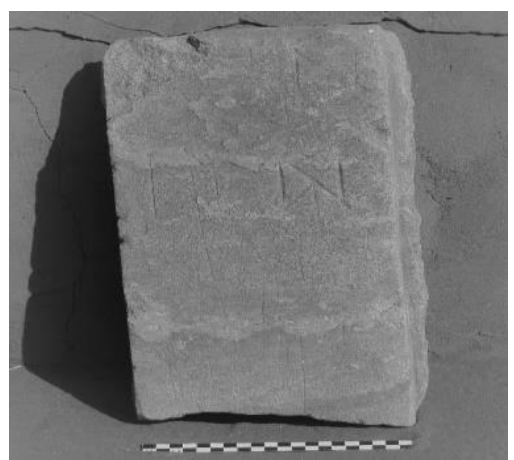

Figure 10: Winged designs as graffiti on architectural block from the storeroom on Sai Island (provenance unknown - probably the fortress) (photo by H. Hafsaas). 
Further research should look at the contexts in which this grapho-linguistic wing-symbol appears in Nubia.

Neither MXГ nor XM fit completely the eight-pointed cross on the capitals on Sai. The perfect match for the eight-pointed cross on the capitals on Sai is $\mathrm{Y} \cap \Theta$ - the cryptogram for MIYAH $\wedge$. The $X$ and $\Pi$ fits the arms of the cross, while the $\Theta$ contributes to the cross in the middle of the symbol (Figure 11).

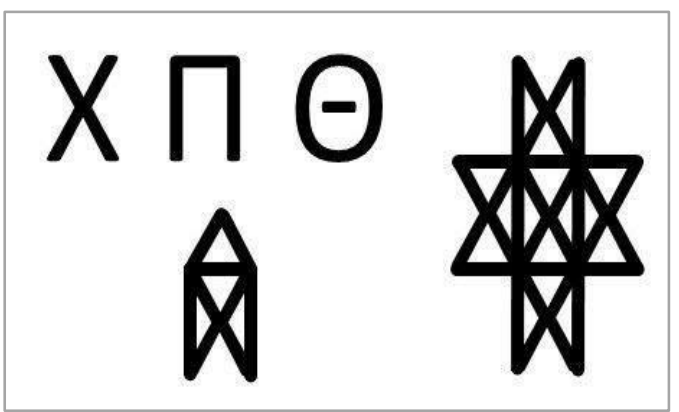

Figure 11: The archangel Michael's cryptogram forming the eight-pointed cross (drawing by H. Hafsaas).

In other words, the superimposed cryptogram of Michael fits all the lines of one of the four segments of the eight-pointed cross, as it was engraved on the capitals of the Cathedral of Sai.

We are persuaded that people in Medieval Nubia apprehended eight-pointed crosses in a grapho-linguistic sense as a symbol of the archangels. The eight-pointed cross was probably also a multivocal symbol, since it appears to have had different meanings and interpretations based on the number of lines in the central part of the cross. The making and interpretation of such symbols required specialized knowledge and skills, as possessed by for instance monks in monastic scriptoria. The apotropaic meaning of these symbols was undoubtedly understood by even illiterate Nubians in medieval times, and they probably associated these eight-pointed crosses with the archangels and their protective powers.

The archangel Michael was popular throughout Nubia. However, the prominent position of the grapho-linguistic symbol of the archangel Michael in the Cathedral of Sai indicates a particularly high status of Michael in the Christian community on Sai Island. Supporting the significance of Michael on Sai is the engraved monogram of Michael, which we discovered on one of the sandstone blocks of the architectural spolia in the fortress and apparently from the cathedral of Sai (Figure 12a).

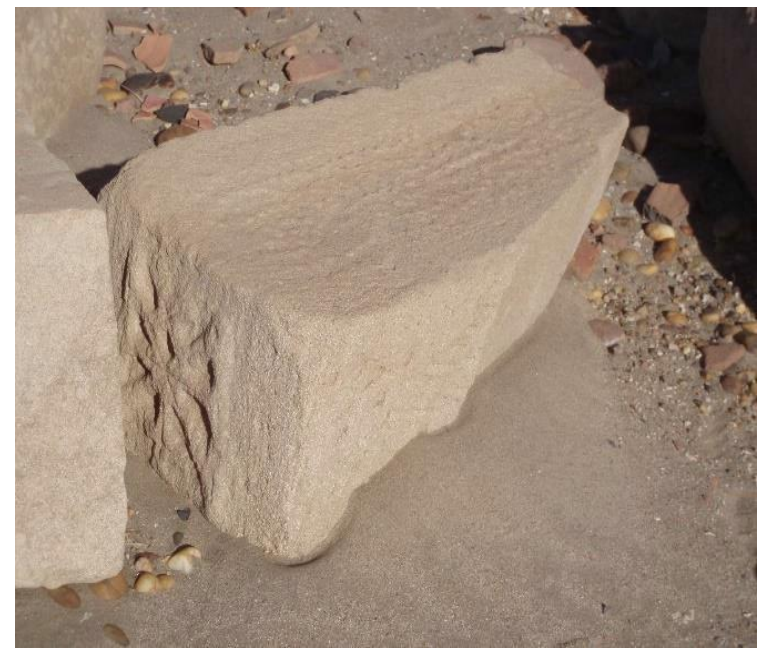

Figure 12a: The archangel Michael's monogram from an architectural block in the Sai fortress (photo H. Hafsaas). 
The monogram is composed of the capital letters of the name in Greek, MIYAH $\wedge$, by using the fewest number of lines (Figure 12b), as described above. This monogram has also been found in other contexts in Nubia - among them as a tattoo on the inner right thigh of a naturally mummified woman from the Fourth Cataract region (Vandenbeusch and Daniel, 2015). The archangel Michael was clearly venerated on Sai Island, and further research may show if the Cathedral of Sai was dedicated to the archangel.

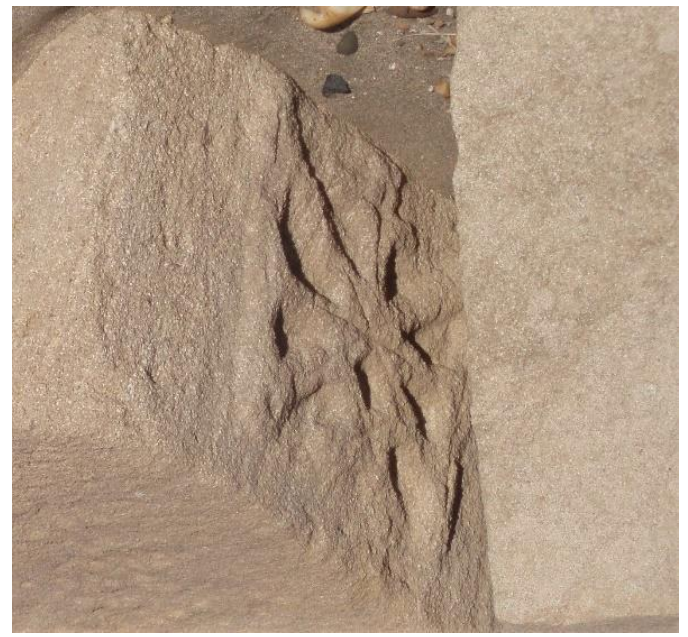

Figure 12b: The monogram from $12 \mathrm{a}$ is turned and enlarged (photo $\mathrm{H}$. Hafsaas)

\section{Conclusion}

In the context of the multilingual Christian Nubian society, where Greek, Coptic, and Old Nubian were widely used, the Greek language retained a sacred character during the entire medieval period (Łajtar and Ochała, 2021: 793). As the sacred language, the Greek alphabet became a vehicle for describing all things holy. Christian Nubians perceived this holiness in an active manner, befitting acts of ritual power. In the socio-religious context of Medieval Nubia, the quote by Timothy, archbishop of Alexandria, mentioned above, assumes fully its role. The quote started with a comparison of the name of Michael to "a strong armour", which is a clear substitute for protection. Then follows the advice of Jesus to write cryptograms for protection. We hope to have demonstrated that for the Christians in Medieval Nubia, the writing of a cryptogram, or the symbols made from them in form of wings or crosses, was a practice invoking the powers of the archangels. The protective powers of the scribal creations of monograms, cryptograms, and grapho-linguistic symbols like the eight-pointed cross in Medieval Nubia are suggested from locations on a cathedral and even on a mummified body.

Since early medieval times, monograms and cryptograms of Michael and the other archangels were symbols of ritual and apotropaic power. By extension, their use in all sorts of combinations, like the eight-pointed crosses in Nubia, made the use of such symbols in invocations to the archangels for protection - with special emphasis on the protective powers of the archangel Michael. The continued use of the eight-pointed cross in traditional clothing often on such vulnerable body parts as the breast and the hands, still reflects the protective powers hidden in this cross-symbol.

In this article, we have interpreted the eight-pointed crosses found on the capitals of the socalled cathedral of Sai as a multivocal symbol connected with the archangels. The cross was made in a grapho-linguistic technic, and the carving of this eight-pointed cross on the capitals on Sai Island probably symbolized the archangel Michael. The monogram of Michael on an architectural block, possibly from the same cathedral, suggests that the cult of the archangel Michael was strong on Sai Island during the medieval period. 


\section{Acknowledgements}

The authors are grateful for the opportunity to work on Sai Island and study its medieval period, and we would like to thank the Sai Island Archaeological Mission (University Charles-de-Gaulle - Lille 3, France), the Section Française d'Archéologie Soudanaise, and the National Corporation of Antiquities and Museums in Sudan. We are also grateful for the support from the University of Bergen, the late philanthropist Mahmoud Salih, the Institute for Comparative Research in Human Culture at the Academy of Norway, the Norwegian foundation of School Teacher Bendixen, the Greek Community of Khartoum, and last but not least the inhabitants of Sai Island.

With acknowledgement to the South African National Institute of the Humanities and the Social Sciences (NIHSS) for financially supporting the research presented in this special edition. (Project CRP20-1032: African Oral art in image-text objects: Cultural translations of precolonial memories and remains)

\section{References}

Adams, W.Y. (1993). Medieval Nubia - Another Golden Age. Expedition, 35/2, 28-39.

Aldsworth, F. (2010). Qasr Ibrim: The Cathedral Church [Excavation Memoir 97]. Egypt Exploration Society, London.

Black, J. and Green, A. (1992). Gods, Demons and Symbols of Ancient Mesopotamia: An Illustrated Dictionary, The British Museum Press, London.

Boyce, M. (2000). "Fravaši". Encyclopaedia Iranica, Vol. X, Fasc. 2. 195-199.

Dornseiff, F. (1925). Das Alphabet in mystik und magie, Berlin.

Gantzhorn, V. (1991). The Christian Oriental carpet: A presentation of its development, iconologically and iconographically, from its beginnings to the $18^{\text {th }}$ century, Benedikt Taschen, Köln.

Garipzanov, I. (2015). The rise of graphicacy in late antiquity and the early Middle Ages, Viator, $46 / 2,1-22$.

Gartkiewicz, P.M. (1990). The Cathedral in Old Dongola and its antecedents [Nubia 1; Dongola 2]. Warsaw: Państwowe Wydawnictwo Naukowe.

Gilhus, I.S. (2019). On the category of angels. In I. S. Gilhus, A. Tsakos \& M.C. Wright (Eds). The Archangel Michael in Africa: history, cult and persona, Bloomsbury Academic, London New York - Oxford - New Delhi - Sydney. 11-21.

Godlewski, W. (2019). The Sacral Architecture in the Kingdom of Makuria. In D. Raue (Ed.). Handbook of Ancient Nubia, De Gruyter, Berlin - Boston. 921-942.

Goody, J. (1987). The Interface between the Written and the Oral. Studies in Literacy, Family, Culture and the State. Cambridge.

Grimal, P. (1996). "Iris". The Dictionary of Classical Mythology. 237-238.

Hafsaas-Tsakos, H. \& Tsakos, A. (2009). "First Glimpses into the Medieval Period on Sai Island". Beiträge zur Sudanforschung, vol. 10. 81-89.

Hafsaas-Tsakos, H. \& Tsakos, A. (2012). "A Second Look into the Medieval Period on Sai Island”. Beiträge zur Sudanforschung, vol. 11. 75-91. 

from Sai Island". In A. Łajtar, A. Obluski \& Y. Zych (Eds). AEgyptus et Nubia Christiana. The Wlodzimierz Godlewski Jubilee Volume on the Occasion of his $70^{\text {th }}$ Birthday. Warsaw. 389-

410.

Heil, G. \&. Ritter, A.M. (Eds), Corpus Dionysiacum, II: De Coelesti Hierarchia, De Ecclesiastica Hierarchia, De Mystica Theologia, Epistulae, 2nd ed., Patristiche Texte, 67, 759, Berlin and Boston: De Gruyter, 2012.

Jakobielski, S. (1991). The inscriptions, ostraca and graffiti. In. D.A. Welsby \& C. M. Daniels (Eds). Soba. Archaeological Research at a Medieval Capital on the Blue Nile. London. 274296.

Jensen, R.M. (2017). The cross: History, art, and controversy, Cambridge, Massachusetts: Harvard University Press.

King, K.L. (2005). What is Gnosticism? Harvard University Press.

Łajtar, A. \& Van der Vliet, J. (2017). Empowering the Dead in Christian Nubia. The Texts from a Medieval Funerary Complex in Dongola. The Journal of Juristic Papyrology Supplement 32. Warsaw.

Łajtar, A. \& Ochała, G. (2020). Language Use and Literacy in Late Antique and Medieval Nubia. In G. Emberling \& B. Williams (Eds). The Oxford Handbook of Ancient Nubia, New York. 788-805.

Müller, C.D.G. (1959). Die Engellehre der koptischen Kirche, Wiesbaden.

Ruffini, G. (2021). The History of Medieval Nubia. In G. Emberling \& B. Williams (Eds). The Oxford Handbook of Ancient Nubia, New York. 759-771.

Ryl-Preibisz, I. (1971). Chapiteaux en granit de Nubie. Études et Travaux, 5. 209-241.

Ryl-Preibisz, I. (1986). On the type of capitals in Christian Nubia. In M. Krause (Ed.), Nubische Studien: Tagungsakten der 5. Internationalen Konferenz der International Society for Nubian Studies, Heidelberg, 22.-25. September 1982. Mainz am Rhein: Philipp von Zabern. 379-384.

Ryl-Preibisz, I. (2001). Elements of architectural decoration from Old Dongola. In S. Jakobielski \& P.O. Scholz (Eds). Dongola-Studien: 35 Jahre polnischer Forschungen im Zentrum des makuritischen Reiches [Bibliotheca Nubica et Aethiopica 7]. Warsaw: ZAS PAN. 367-387.

Spiro, M.E. (1966). Religion: problems of definition and explanation, In M. Banton (Ed.). Anthropological approaches to the study of religion, London. 85-126.

Tsakos, A. (2011-2012). Medieval Funerary Stelae from the Island of Sai. Cahiers de Recherches de l'Institut de Papyrologie et d'Égyptologie de Lille, 29. 297-330.

Tsakos, A. (2015). The cryptogram МYГ as a variant of the cryptogram ХМГ: on text, image, and Christian faith in medieval Nubia. In A. Łajtar, G. Ochała, \& J. Van der Vliet (Eds). Nubian Voices II: New texts and studies in Christian Nubian Culture, Warsaw. 245-62.

Tsakos, A. (forthcoming a). Invoking archangels graphically: The archangel Michael in Christian Nubia as a Case Study. In: D. Lauritzen (Ed.). Inventer les anges de l'Antiquité à Byzance. Paris. 

Ithaca and London.

Vandenbeusch, M. \& Daniel, A. (2015). Under Saint Michael's protection: A tattoo from Christian Nubia. Journal of the Canadian Centre for Epigraphic Documents 1. 15-19.

Ware, C. (2013). Information visualization: Perception for design, 3rd ed., Elsevier/Morgan Kaufmann, Amsterdam. 